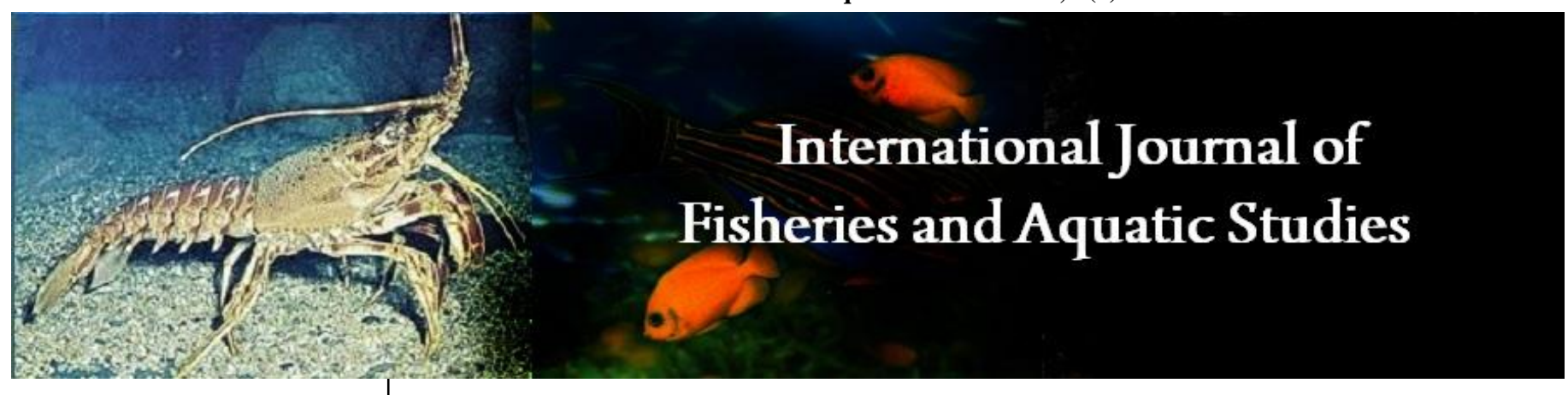

E-ISSN: 2347-5129

P-ISSN: 2394-0506

(ICV-Poland) Impact Value: 5.62

(GIF) Impact Factor: 0.549

IJFAS 2021; 9(1): 328-332

(C) 2021 IJFAS

www.fisheriesjournal.com

Received: 28-11-2020

Accepted: 30-12-2020

Amadou Guissé

Laboratory of Biological,

Agronomic and Food Sciences

and Complex Systems Modeling

of the Gaston Berger University

of Saint-Louis, Senegal

Farokh Niass

Laboratory of Biological,

Agronomic and Food Sciences

and Complex Systems Modeling

of the Gaston Berger University

of Saint-Louis, Senegal
Corresponding Author:

Amadou Guissé

Laboratory of Biological,

Agronomic and Food Sciences

and Complex Systems Modeling

of the Gaston Berger University

of Saint-Louis, Senegal

\section{Weight-length relationship and condition factor of Sarotherodon melanotheron (Rüppell, 1852) in the special wildlife reserve of Gueumbeul (RSFG) in Senegal}

\author{
Amadou Guissé and Farokh Niass
}

DOI: https://doi.org/10.22271/fish.2021.v9.i1d.2420

\begin{abstract}
The Special Wildlife Reserve of Gueumbeul (RSFG) consists of a water reservoir (the basin) frequented by a diversity of fish and migratory birds. The most represented in terms of abundance is the species Sarotherodon melanotheron. The objective of this study was to determine the relations weight-length and to characterize the condition factor of S. melanotheron, in the basin of Gueumbeul. A total of 628 fish were sampled including 364 males, 178 females and 86 immature individuals from March 2019 to February 2020. The total length (TL) of S. melanotheron specimens sampled in the Gueumbeul reserve ranged from $6.1 \mathrm{~cm}$ to $17.6 \mathrm{~cm}$ with an average of $11.08 \pm 1.82 \mathrm{~cm}$ and the weight (W) from $4.8 \mathrm{~g}$ to 103 $\mathrm{g}$ with an average of $27.25 \pm 12.09 \mathrm{~g}$. The results of the weight-length analyses gave values of 2.69 and 2.77 for the regression coefficient (b) for males and females respectively, and 2.72 and 2.76 for the dry and wet seasons. This reflects negative allometric growth in both sexes (male and female) and by season (dry and wet season). No statistically significant difference was noted for dry and wet season $\mathrm{b}$ values for $S$. melanotheron in the Gueumbeul basin, unlike condition factors between males and females and between dry and wet season where significant differences in $\mathrm{K}$ values were noted.
\end{abstract}

Keywords: length-weight relationship, condition factor, Sarotherodon melanotheron, Gueumbeul basin, Saint-Louis

\section{Introduction}

Most African aquatic ecosystems are currently affected by climate change and the development of anthropogenic activities, the main ones being the scarcity of rainfall leading to long droughts, industrial deforestation, construction of hydroelectric dams and irrigation of agricultural land, overexploitation due to fishing and various forms of pollution ${ }^{[1]}$. All of these phenomena and practices are exerting increasing pressure on exhaustible natural resources and endangering aquatic fauna, especially fish in various hydrosystems ${ }^{[1]}$. However, the protection of aquatic ecosystems with a view to rational management of its biodiversity is currently becoming a major concern for all scientific communities and non-governmental organizations. Among the aquatic organisms taken from the various African water bodies and rivers, fish constitute the major part.

The weight-length relationship is an important tool in biology, physiology, ecology and fish stock assessment ${ }^{[2-4]}$. Indeed, this tool is a widely used approach in fisheries management and environmental monitoring programmes in many respects, as it provides information on the status of fish stocks in an aquatic ecosystem ${ }^{[5]}$ to allow morphological comparisons of populations in different regions ${ }^{[6,7]}$. This relationship also allows the study of ontogenetic allometric changes in fish growth ${ }^{[8]}$. Furthermore, the condition factor is also a morphometric index frequently used to assess the physiological condition of fish based on the principle that individuals of a given length with a higher mass are in better condition ${ }^{[9]}$.

Growth is a fundamental characteristic of all living organisms and the growth pattern and growth rates are very species-specific ${ }^{[10]}$ and vary from one aquatic ecosystem to another within the same species. Growth can be isometric when the organ grows at the same rate as the rest of the body, whereas allometric growth occurs when an organ grows at a different rate 
from the rest of the animal's body [11, 12]. However, it is important to assess the type of growth for each species in each aquatic ecosystem through the weight-length relationship and the condition factor to take necessary management measures. Sarotherodon melanotheron (Rüppell, 1852), is a cichlid fish widely distributed in West Africa, particularly in the Senegal River ${ }^{[13]}$. This fish, which inhabits the reservoir of the Gueumbeul basin in the Saint-Louis region, is highly appreciated for its tender flesh, its availability and its affordable price for local populations. Thus, it is heavily fished in the basin by artisanal subsistence fishing practically all year round and by the birdlife that frequents the Gueumbeul basin reservoir during the migration and egglaying seasons. Given this situation, it is important to establish conservation measures for the populations of $S$. melanotheron of the Gueumbeul basin. However, these measures can only be effective if studies of fish diversity, biology and ecology are first undertaken ${ }^{[14]}$. To contribute to the rational management of the $S$. melanotheron population in the basin, the present study was envisaged to provide useful information on their growth pattern.

\section{Materials and Methods}

\subsection{Study environment and sampling site}

The Special Wildlife Reserve of Gueumbeul (RSFG) is located in the delta of the Senegal River, more precisely in the department of Saint-Louis (Figure 1). It straddles the rural communities of Ndiébène Gandiole and Gandon. The decree $\mathrm{n}^{\circ}$ 83-550 of 30 May 1983, created it on a surface area of 720 ha for a perimeter of $12 \mathrm{~km}$, including the Gueumbeul basin and the adjacent zone over a width of $500 \mathrm{~m}$ from the edge of the basin. Its geographical coordinates are around $15^{\circ} 59$ North and $16^{\circ} 28$ West.

The climate is of the Sahelo-Sudanian type with a rainfall of 200 to $300 \mathrm{~mm}$ per year and mild temperatures. The latter vary between $21{ }^{\circ} \mathrm{C}$ and $24{ }^{\circ} \mathrm{C}$ from December to May and between $25^{\circ} \mathrm{C}$ and $29{ }^{\circ} \mathrm{C}$ from April to November. The low thermal amplitudes and mild temperatures throughout the year are a consequence of the oceanic influence.

Four sampling sites were selected. This choice was inspired by the fishing activities of the riparian populations and the frequentation of fish-eating birds. The geographical coordinates of each sampling point are shown in Table 1.

Table 1: Sampling Sites Upstream and Downstream of the Gueumbeul Basin

\begin{tabular}{|c|c|c|c|}
\hline Sampling Sites & Site Code & Latitude & Longitude \\
\hline Al Bar Bridge & P_AB & $15^{\circ} 54^{\prime} 03^{\circ} \mathrm{N}$ & $16^{\circ} 27^{\prime} 43^{\circ} \mathrm{W}$ \\
\hline Bountou-Batt Bridge & P_BB & $15^{\circ} 54^{\prime} 14^{\circ} \mathrm{N}$ & $16^{\circ} 28^{\prime} 17^{\circ} \mathrm{W}$ \\
\hline Ndiakhére Bridge & P_Nd & $15^{\circ} 55^{\prime} 47^{\circ} \mathrm{N}$ & $16^{\circ} 27^{\prime} 25^{\circ} \mathrm{W}$ \\
\hline Medium Cell & M_Cu & $15^{\circ} 55^{\prime} 12^{\circ} \mathrm{N}$ & $16^{\circ} 27^{\prime} 47^{\circ} \mathrm{W}$ \\
\hline
\end{tabular}

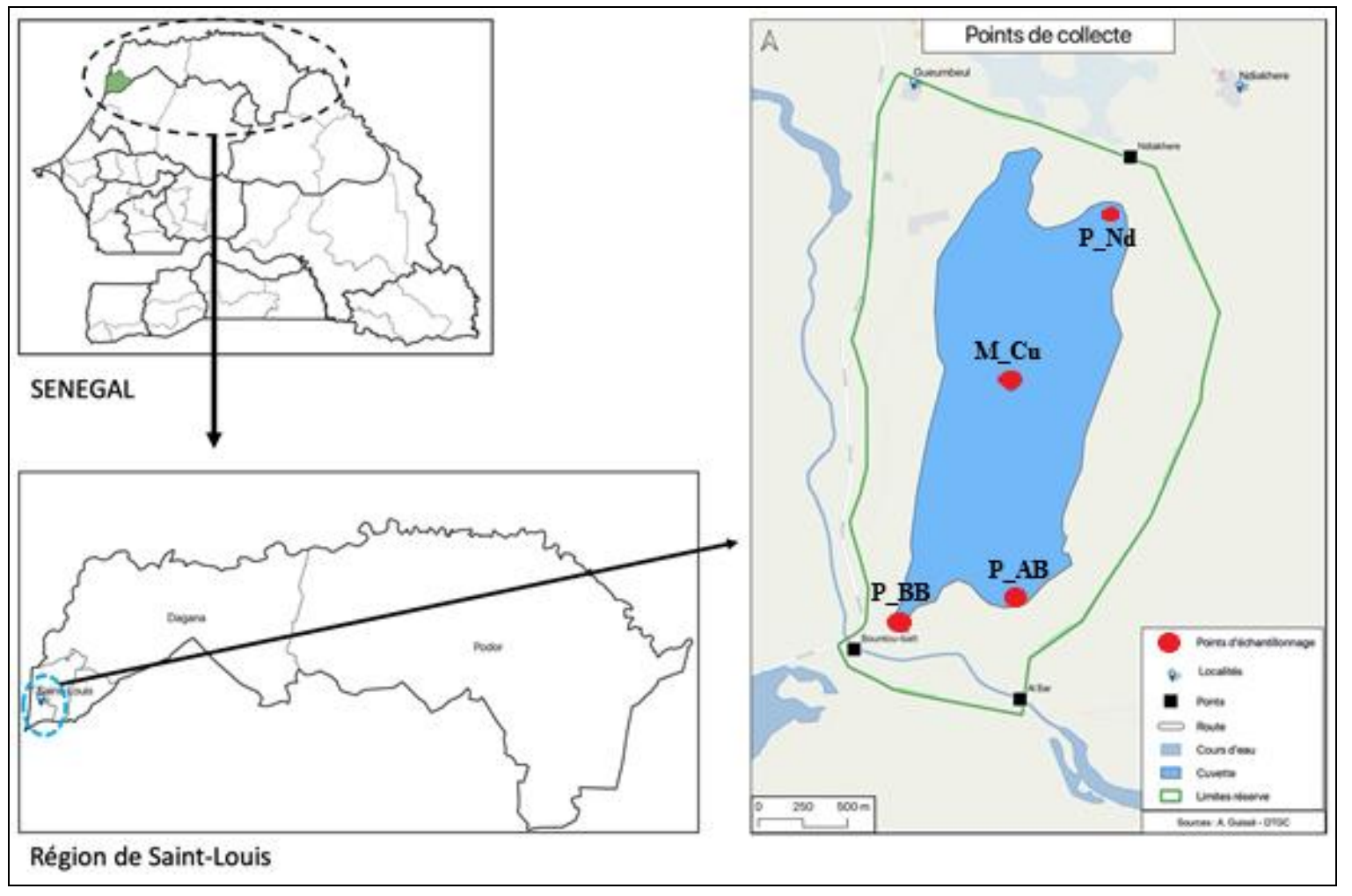

Fig 1: Map of the study area showing the sampling stations in the Gueumbeul basin reservoir

\subsection{Fish sampling and identification}

The reservoir of the Gueumbeul basin was divided into four sampling stations to cover almost the entire body of water. Samples of Sarotherodon melanotheron were taken monthly from March 2019 to February 2020. The rainy season extends from July to September and the dry season from October to June in the study area. Sampling was carried out using cast nets by local fishermen. The identification keys of Melanie et $a l .{ }^{[15]}$; Seret and Opic ${ }^{[16]}$; Bellemans et al. ${ }^{[17]}$; and Lévêque et al. ${ }^{[18]}$ were used to identify the fish. A few specimens of $S$. melanotheron were photographed and fixed with $10 \%$ formalin for conservation purposes.

\subsection{Morphological analyses}

After capture, the fish were immersed in ice and then transported to the Laboratory of Biological, Agronomic and Food Sciences and Complex Systems Modeling (LaBAAM) of the Gaston Berger University of Saint-Louis for measurements and treatment. In the laboratory, the individuals were measured (total length, standard length) then 
weighed (total weight, eviscerated weight) respectively with an ichthyometer calibrated to the nearest $\mathrm{cm}$ and an electronic scale (Scout Pro) with an accuracy of $0.1 \mathrm{~g}$.

\subsection{Length-weight relationship and fish condition factor}

The estimation of the weight-length relationship was done using the equation: $\mathrm{W}=\mathrm{a} \mathrm{L}^{\mathrm{b}}$ from ${ }^{[19]}$ where $\mathrm{W}=$ weight $(\mathrm{g})$, $\mathrm{L}=$ total length $(\mathrm{cm}), \mathrm{b}=$ growth exponent, $\mathrm{a}=$ constant. The value of $b$ gives information on the growth type of fish. Growth is said to be isometric if $b=3$ and allometric if $b \neq 3$ (positive if $b>3$ and negative if $b<3$ ). The value of $b$ is between 2.5 and 3.5 and provides information on growth dimensions or an interpretation of individual well-being ${ }^{[6]}$. A logarithmic transformation was done to make the relationship linear: $\log \mathrm{W}=\log \mathrm{a}+\mathrm{b} \log \mathrm{L}$.

According to Le Cren ${ }^{[19]}$, the coefficient $b$ is logically close to 3 . If $\mathrm{b}<3$, height increases faster than mass and conversely if $b>3$, it is said that there is positive allometry. If $b=3$, there is isometry; the shape does not change. This shape index reflects nutritional status and therefore trophic environmental conditions and physiological status.

The correlation $r$, which is the degree of association between length and weight, was calculated from linear regression analysis: $\mathrm{R}=\mathrm{r}^{2}$

The condition factor $(K)$ of the fish specimens was estimated from the relation:

$\mathrm{K}=100 \mathrm{~W} / \mathrm{L}^{\mathrm{b}}$ where $\mathrm{K}=$ condition factor, $\mathrm{W}=$ weight of fish $(\mathrm{g}), \mathrm{L}=$ length of fish $(\mathrm{cm})$.

For each sex, the slopes of the weight-length regressions were compared to 3 using Student's t-test ${ }^{[20]}$ to determine whether the species grew isometrically or not.

\section{Results}

\subsection{Morphometric characteristics}

The total length (TL) of $S$. melanotheron specimens sampled in the Gueumbeul reserve ranged from $6.1 \mathrm{~cm}$ to $17.6 \mathrm{~cm}$ with an average of $11.08 \pm 1.82 \mathrm{~cm}$ and the weight (W) from $4.8 \mathrm{~g}$ to $103 \mathrm{~g}$ with an average of $27.25 \pm 12.09 \mathrm{~g}$. Male individuals were larger $(17.6 \mathrm{~cm} \mathrm{LT})$, while females had a higher weight (W) at $103 \mathrm{~g}$ compared to the largest male at $88.7 \mathrm{~g}$. However, concerning seasons (dry and wet), the largest specimens in terms of size and weight were recorded during the wet season.

\subsection{Weight-length relationship}

The weight-length relationship equations were calculated separately for males and females (Figures 2 and 3) and for dry and wet seasons (Figures 4 and 5). The regression coefficients as well as the results of the weight-length analysis are presented in Tables 2 and 3. The equations were calculated by the method of least squares for male, female and both seasons (dry and wet) for S. melanotheron. The parameters of the weight-length relationships for males and females were not significantly different $(\mathrm{p}<0.05)$ with $\mathrm{R}$ values greater than 0.90 for both sexes. The slopes (b-values) of the weightlength relationship were 2.69 for males and 2.77 for females. While, the values of the regression coefficient (b), by season (dry and wet), were 2.72 and 2.76, respectively. These values of $b$ were not significantly different $(\mathrm{p}<0.05)$. Also, the correlation coefficient values were 0.92 for the dry season and 0.96 for the wet season. The results showed negative allometric growth, for both sexes and during both seasons, indicating that the species $S$. melanotheron, in the Gueumbeul basin, tends to grow more in size than in weight. The condition factors $(\mathrm{K})$ obtained were 3.76 for males and 3.33 for females and 3.47 and 3.38 respectively for the dry and wet seasons. A significant difference was noted between the $\mathrm{K}$ values for males and females on the one hand and between the two seasons (dry and wet) on the other hand.

Table 2: Equations and growth parameters of $S$. melanotheron by sex (male and female) in the GSFR basin. $\mathrm{n}=$ number of individuals, $\mathrm{a}=$ intercept, $\mathrm{b}=$ the slope of the regression line, $\mathrm{r}^{2}=$ the correlation coefficient and $\mathrm{K}=$ condition factor

\begin{tabular}{|c|c|c|c|c|c|c|c|}
\hline Species & Gender & Equations & $\mathbf{n}$ & $\mathbf{a}$ & $\mathbf{b}$ & $\mathbf{r}^{\mathbf{2}}$ & $\mathbf{K}$ \\
\hline $\begin{array}{l}\text { Sarotherodon } \\
\text { melanotheron }\end{array}$ & Male & $\mathrm{W}=0,0373 \mathrm{~L}^{2,6954}$ & 364 & 0,037 & 2,69 & 0,93 & 3,76 \\
\cline { 2 - 8 } & Female & $\mathrm{W}=0,033 \mathrm{~L}^{2,7665}$ & 178 & 0,033 & 2,77 & 0,92 & 3,33 \\
\hline
\end{tabular}

Table 3: Equations and parameters for the growth of $S$. melanotheron by season (dry and wet) in the RSFG basin. $\mathrm{n}=$ number of individuals, a $=$ intercept, $\mathrm{b}=$ the slope of the regression line, $\mathrm{r}^{2}=$ the correlation coefficient and $\mathrm{K}=$ condition factor

\begin{tabular}{|c|c|c|c|c|c|c|c|}
\hline Species & Season & Equations & $\mathbf{n}$ & $\mathbf{a}$ & $\boldsymbol{b}$ & $\mathbf{r}^{\mathbf{2}}$ & $\mathbf{K}$ \\
\hline \multirow{2}{*}{$\begin{array}{l}\text { Sarotherodon } \\
\text { melanotheron }\end{array}$} & Dry & $\mathrm{W}=0,0345 \mathrm{~L}^{2,7242}$ & 306 & 0,034 & 2,72 & 0,92 & 3,47 \\
\cline { 2 - 9 } & Rainy & $\mathrm{W}=0,0335 \mathrm{~L}^{2,7563}$ & 323 & 0,033 & 2,76 & 0,96 & 3,38 \\
\hline
\end{tabular}

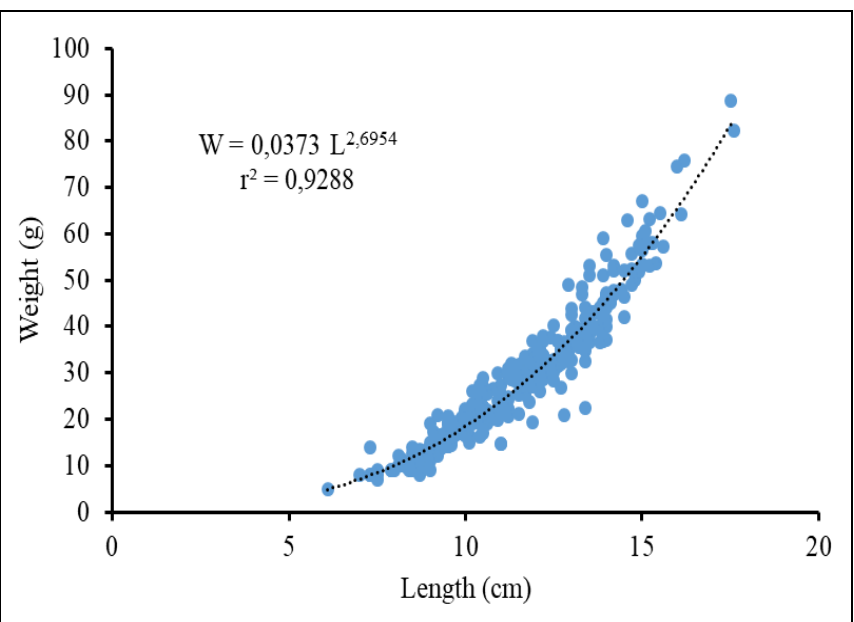

Fig 2: Weight-Length Relationship of Male S. melanotheron

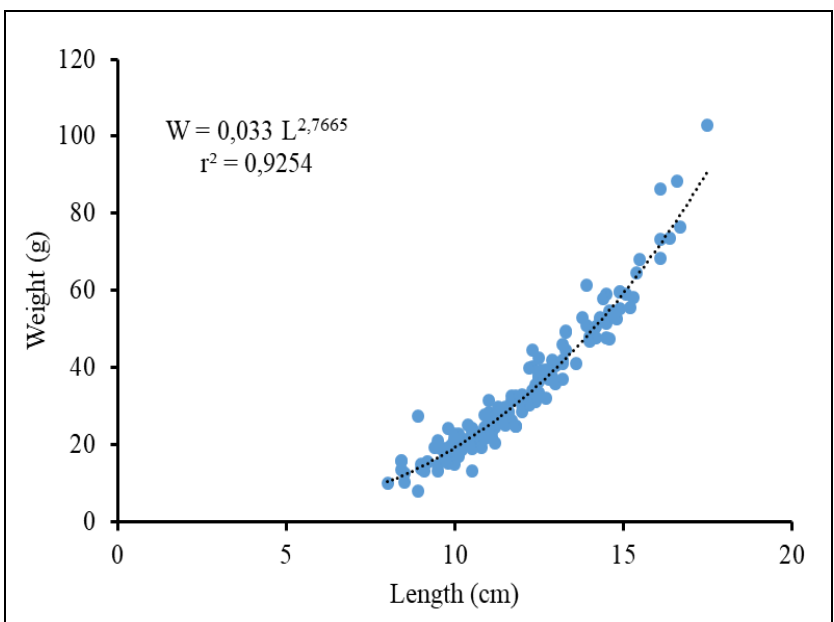

Fig 3: Relation poids-longueur de $S$. melanotheron femelles 


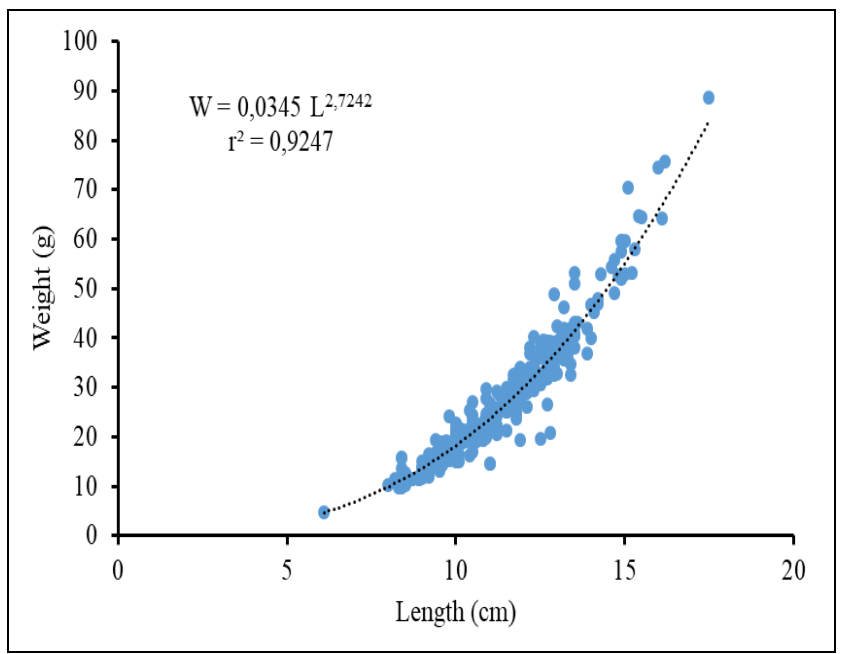

Fig 4: Weight-length relationship of S. melanotheron during the dry season

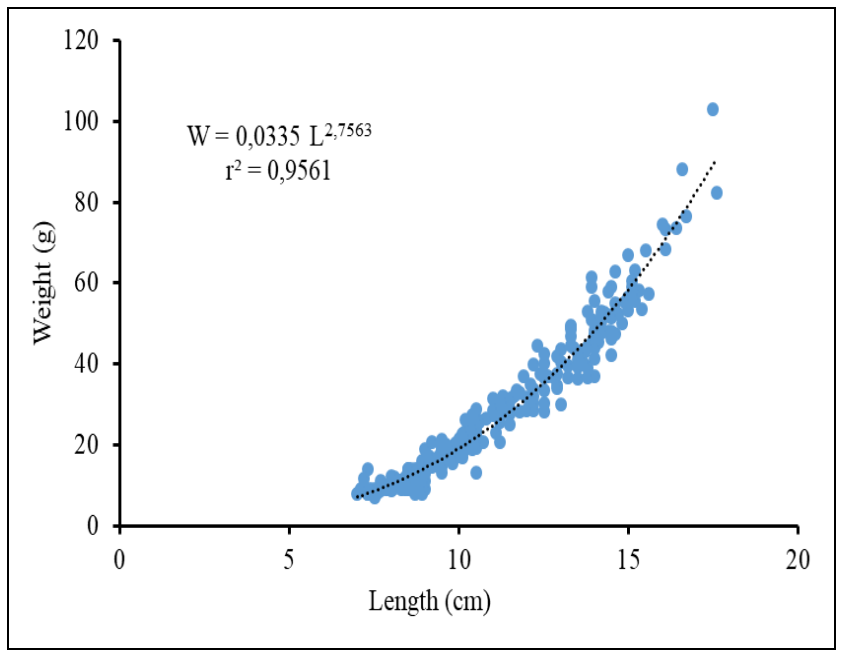

Fig 5: Weight-length relationship of S. melanotheron during the rainy season

\section{Discussion}

Values for b may be influenced by sex, growth stage, stomach contents, environmental conditions according to Baby et al. [21] and level of gonad development ${ }^{[22]}$. As shown by the equations in Table 1 , the values of $b$ for males and females were significantly different. However, no significant difference was obtained in b values between dry and wet seasons. The $b$ values obtained were within the range indicated by Froese ${ }^{[23]}$, saying that the $b$ parameter should normally be between 2.5 and 3.5. In males, females and by season, the regression coefficients (b) of $S$. melanotheron were significantly different from 3 , indicating a negative allometric growth $(\mathrm{b}<3$ ) in the $S$. melanotheron population in the Gueumbeul Reserve. This pattern of growth obtained in $S$. melanotheron in this ecosystem would be linked to the phenomenon of sexual dimorphism and variations in the availability of food resources and biological and ecological factors between seasons. This negative allometry is similar to those obtained by Chikou ${ }^{[24]}$ in several water reservoirs in Benin (b ranged from 2.55 to 2.76), and those obtained by Ecoutin and Albaret ${ }^{[25]}$ in the Ebrié lagoons in Côte d'Ivoire $(b=2.78)$ and Sine Saloum in Senegal $(b=2.81)$. These results are different from those found by Mireku et al. ${ }^{[26]}$ in the Brimsu reservoir in Ghana with $b$ values that ranged from 3.95 to 4.94 for males and 4.08 to 4.99 for females, by Lalèyè [14] in the Ouémé River in Benin where the values of the regression coefficient b (3.07) were not significantly different from 3 and those obtained by Ndimele et al. ${ }^{[27]}$ for the same species ( $S$. melanotheron) in Lake Ologe, Nigeria with b values ranging from 3.09 to 3.12. The correlation coefficient $\left(R^{2}\right)$ values for males, females were 0.92 and 0.93 respectively while dry season values were 0.92 and 0.96 for the wet season. These results show that there is a strong correlation between the length and weight of $S$. melanotheron species in the Gueumbeul basin. No significant difference was noted in the values of the correlation coefficients (R). However, a seasonal variation in the condition factor of $S$. melanotheron was recorded in the Gueumbeul reserve. It was respectively 3.76 and 3.33 for males and females and 3.47 and 3.38 for the dry and wet season. This seasonal variation in the $\mathrm{K}$ value could be because, during the rainy season, the fish devote part of their energy to reproduction, which probably decreases their condition. Oni et al. ${ }^{[28]}$ noted that the condition factor is not constant for a species or population over time and may be influenced by both biotic and abiotic factors such as diet and gonadal development status.

\section{Conclusion}

The present study is the first to provide information on the weight-length relationship and condition factor in $S$. melanotheron in the Special Wildlife Reserve of Gueumbeul. The results obtained constitute an important database for researchers and managers of the Reserve in the elaboration of management and conservation measures for the fish populations of the basin.

\section{Conflict of Interest}

The authors announce no conflict of interest with the contents of this article.

\section{References}

1. Paugy D, Levêque C. Impacts of human activities. In: Paugy D. Levêque C. \& Otero O. (eds) : The inland water fishes of Africa: Diversity, Ecology and Human use, Institut de Recherche pour le Développement (IRD), Royal Museum for Central Africa (RMCA), 2017, 459478.

2. Beyer JE. On length-weight relationship. Part-I: Computing the mean weight of the fish of a given length class. Fishbyte 1987;5:11-13. doi: https://hdl.handle.net/20.500.12348/3367

3. Bolognini L, Domenichetti F, Grati F, Polidori P, Scarcella G, Fabi G. Weight-Length Relationships for 20 Fish Species in the Adriatic Sea, Turkish Journal of Fisheries and Aquatic Sciences 2013;13:555-560. doi: 10.21411 / CBM.A.AA0D91E6

4. Mikembi ALB, Zamba AI, Mamonekene V, Tenda HDL, Ngot FHP, Vouidibio J Relations longueurs-poids et coefficients de condition pour 13 espèces de poissons de la rivière Dzoumouna, affluent du cours inférieur du fleuve Congo (République du Congo). Journal of Animal \& Plant Sciences 2019;39:6384-6393. doi: http://www.m.elewa.org/JAPS

5. Bagenal TB, Tesch FW. Age and growth. In: Methods for assessment of fish production in fresh waters, 3rd edn. T. Begenal (Ed.). IBP Handbook No. 3, Blackwell Science Publications, Oxford 1978,101-136.

doi: $10.1111 /$ jai.12015

6. Petrakis G, Stergiou KI. Weight-length relationships for 33 fish species in Greek waters. Fisheries Research, 
1995;21:465-469. doi: https://doi.org/10.1016/01657836(94)00294-7

7. Lorenzen K. Population dynamics and management. Pp. 163-225. In: Beveridge MCM, McAndrew BJ, éds, Tilapias: Biology and Exploitation. Kluwer Academic Publishers, Great Britain, Fish and Fisheries series 2000, 25. doi: 10.1007 / 978-94-011-4008-9_6

8. Teixeira-de Mello F, Iglesias C, Borthagaray AI, Mazzeo $\mathrm{N}$, Vilches J, Larrea D et al. Onthogenic allometric coefficient changes. Implicances of diet shift and morphometric attributes in Hoplias malabaricus (Bloch) (Characiforme, Erythrinidae). J Fish Biol 2006;69:17701778.

9. Alexander J, Barrios R. Influence des variations des facteurs environnementaux sur la croissance des poissons de l'atlantique. Biodiversité et Ecologie. Agrocampus Ouest. Français 2017, doi: https://tel.archivesouvertes.fr/tel-01661628

10. Olopade OA, Taiwo IO, Ogunbanwo AE. Length-weight relationship and condition factor of Leuciscus niloticus (De Joahhis, 1853) from Epe Lagoon, Lagos State, Nigeria. Ege Journal of Fisheries and Aquatic Sciences, 2015;32:165-168. doi: https://livedna.org/234.15859

11. Dumas A, France J, Bureau D. Modelling growth and body composition in fish nutrition: where have we been and where are we going? Aquaculture Research 2010;41:161-181. doi: https://doi.org/10.1111/j.13652109.2009.02323.x

12. Taylor DJ, Green NPO, Stout GW, Soper R. Biological Science. Third edition, Cambridge University Press, London 2005, 389.

13. Pouyaud L. Systématique et évolution des poissons d'intérêt économique des eaux douces tropicales, HDR Université Montpellier, (France) 2007, doi: https://www.researchgate.net/publication/301698711

14. Lalèyè $P$. Length-weight and length-length relationships of fishes from the Ouémé River in Bénin (West Africa). Journal of Applied Ichthyolology 2006;22:330-333. doi: http://dx.doi.org/10.12692/ijb/14.1.96-100

15. Melanie LJ, Stiassny GG, Teugels CD, Hopkins. Poissons d'eaux douces et saumâtres de basse Guinée, ouest de l'Afrique centrale. Tome II. Faune et Flore tropicales 42. Paris 2007.

16. Seret B, Opic P. Poissons de mer de l'ouest africain tropical. Initiations-documentations techniques $N^{\circ} 49$. Paris (France).

17. Bellemans M, Sagna A, Fischer W, Scialabba N. Guide des ressources halieutiques du Sénégal et de la Gambie (Espèces marines et d'eaux saumâtres). Fiches FAO d'identification des espèces pour les besoins de la péche, Rome, Italie 1988,

18. Lévêque C, Pagy D, Teugels GG. Faune des poissons d'eaux douces et saumâtres de l'Afrique de l'ouest. Tome I. Faune tropicale, XXVIII, MRACTervuren / ORSTOMParis 1990,

19. Le Cren ED. The length-weight relationship and seasonal cycle in gonad weight and condition in the perch (Perca fluviatilis). J. Anim. Ecol 1951;20:2-19.

20. Sokal R, Rohlf F. Biometry: the principles and practice of statistics in biological research. 2nd ed. 10.2307/2343822. Tesch FW. 1971. Age and growth. In: Ricker WE. (Ed.). Methods for assessment of fish production in fresh waters. Blackwell Scientific Publications, Oxford 1987, 98-130.
21. Baby F, Tharian J, Abraham KM, Ramprasanth MR, Ali A, Ranghavan R. Length-weight relationship and condition factor of an endemic stone sucker, Garra gotyla stenorhynchus (Jerdon, 1849) from two opposite flowing rivers in southern Western Ghats. Journal of threatened taxa 2011;3(6):1851-1855. ISSN 0974-7907 (online)|0974-7893 (print).

22. Hossain MY, Ahmed ZF, Leunda PM, Jasmine S, Oscoz J, Miranda R Condition, length-weight and length-length relationships of the Asian striped catfish Mystus vittatus (Bloch, 1794) (Siluriformes: Bagridae) in the Mathabhanga River, Southwestern Bangladesh. Journal of Applied Ichthyology 2006;22:304-307.

doi: https://doi.org/10.1111/j.1439-0426.2006.00803.x

23. Froese R. Cube law, condition factor and weight-length relationships: history, meta-analysis and recommendations. Journal of Applied Ichthyology, 2006;22:241-253. doi: https://doi.org/10.1111/j.14390426.2006.00805.x

24. Chikou A. Length-weight relationships of Sarotherodon melanotheron melanotheron (Pisces: Cichlidae) in Benin (West Africa), International Journal of Biosciences, 2019;14(1):96-100. doi: http://dx.doi.org/10.12692/ijb/14.1.96-100

25. Ecoutin JM, Albaret JJ. Relation longueur-poids pour 52 espèces de poissons des estuaires et lagunes de l'Afrique de l'Ouest. Cybium. 2003;27(1):3-9. doi: http://www.documentation.ird.fr/hor/fdi:010031401

26. Mireku KK, Blay J, Yankson K. Reproductive biology of Blackchin tilapia, Sarotherodon melanotheron (Pisces: Cichlidae) from Brimsu Reservoir, Cape Coast, Ghana. International Journal of Fisheries and Aquaculture, 2016;8(4):42-54. doi: 10.5897 / IJFA2015.0511

27. Ndimele PE, Kumolu-Johnson CA, Aladetohun NF, Ayorinde OA. Length-weight relationship, condition factor and dietary composition of Sarotherodon melanotheron, Rüppell, 1852 (Pisces: cichlidae) in Ologe Lagoon, Lagos, Nigeria. Agriculture and biology journal of North America, ScienceHuß 2010, doi : http://www.scihub.org/ABJNA.

28. Oni SK, Olayemi JY, Adegboye JD. The comparative physiology of three ecologically (Rupel). Synodonts schall. Block and Schneider and Tilapia zilli (Gervais). Journal of Fish Biology 1983;22:105-109. doi: https://doi.org/10.1111/j.1095-8649.1983.tb04730.x 